\title{
PERKEMBANGAN BANK SYARIAH DI INDONESIA
}

\author{
Tira Nur Fitria \\ STIE AAS Surakarta
}

Email: tiranurfitria@gmail.com

\begin{abstract}
This study aims to find out about the development of Islamic banks in Indonesia. This research is qualitative descriptive. This study included literature to examine the written sources such as scientific journals, books referesni, literature, encyclopedias, scientific articles, scientific papers and other sources that are relevant and related to the object being studied. As for the object of study of this research is in the form of texts or writings that describe and explain about the development of Islamic banks in Indonesia. Results from this study is Indonesian banking now enlivened by the presence of Islamic banks, which offers financial products and investment in a different way than conventional banks, as Indonesia is the largest Muslim country in the world. The development of Islamic banking in Indonesia has become a benchmark for the success of the Islamic economic existence. Bank Muamalat as the first Islamic bank and a pioneer for other Islamic banks in Indonesia.
\end{abstract}

Keywords: Islamic banks, conventional banks, banking

\section{PENDAHULUAN}

Kegiatan ekonomi ini sudah ada sejak jaman Rasulullah SAW. Oleh karena itu banyak pro kontra ekonomi yang dihadapi manusia, maka ahli pikir mulai memikirkan bagaimana mengubah seni ekonomi menjadi ilmu ekonomi seperti yang ada sekarang ini. Ilmu ekonoomi ini akan terus berkembang sesuai dengan perkembangan peradaban manusia. Pada masa sekarang ini banyak bermunculan perbankan syariah dengan banyaknya perkembangan syariah. Ekonomi konvensional memang masih lebih diatas ekonomi syariah. Para ekonom mempridiksi tahun-tahun yang akan datang ekonomi syariah akan berkembang lebih pesat dari ekonomi konvensional.
Di zaman Nabi SAW belum ada institusi bank, tetapi ajaran Islam sudah memberikan prinsip prinsip dan filosofi dasar yang harus dijadikan pedoman dalam aktifitas perdagangan dan perekonomian. Karena itu, dalam menghadapi masalah muamalah kontemporer yang harus dilakukan hanyalah mengidentifikasi prinsip-prinsip dan filosofi dasar ajaran Islam dalam bidang ekonomi, dan kemudian mengidentifkasi semua hal yang dilarang. Setelah kedua hal ini dilakukan, maka kita dapat melakukan inovasi dan kreativitas (ijtihad) seluas-luasnya untuk memecahkan segala persoalan muamalah kontemporer, termasuk persoalan perbankan. 
Perbankan pada saat ini, khususnya Bank umum merupakan inti sistem keuangan setiap negara. Bank memiliki usaha pokok berupa menghimpun dana dari pihak yang berlebihan dana untuk kemudian menyalurkan kembali dana tersebut ke masyarakat yang kekurangan dana dalam jangka waktu tertentu. Fungsi untuk mencari dan selanjutnya menghimpun dana dalam dalam bentuk simpanan sangat menentukan pertumbuhan suatu bank, sebab volume dana yang berhasil dihimpun atau disimpan tentunya akan menentukan pula volume dana yang dapat dikembangkan oleh bank tersebut dalam bentuk penanaman dana yang menghasilkan.

Kehadiran dan fungsi perbankan di Indonesia baik untuk masyarakat, industri besar, menengah atau bawah mempunyai peranan dan pengaruh yang sangat signifikan. Hal ini terjadi karena kebutuhan akan bank baik untuk penguatan modal atau penyimpanan uang oleh masyarakat sudah menjadi hal yang biasa. Dalam mengantisipasi kebutuhan masyarakat serta memberikan rasa aman, nyaman dalam transaksi perbankan, kehadiran Bank Syariah merupakan salah satu solusi untuk menambah kepercayaan masyarakat terhadap kegiatan perbankan khususnya di Indonesia.

Bank Syariah merupakan salah satu produk perbankan yang berlandaskan sistem perekonomian Islam, Sistem Ekonomi Islam atau syariah sekarang ini sedang banyak diperbincangkan di Indonesia. Banyak kalangan masyarakat yang mendesak agar Pemerintah Indonesia segera mengimplementasikan sistem Ekonomi Islam dalam sistem Perekonomian
Indonesia seiring dengan hancurnya sistem Ekonomi Kapitalisme.

$$
\text { Bank Syariah pada awalnya }
$$
dikembangkan sebagai suatu respon dari kelompok ekonomi dan praktisi perbankan muslim yang berupaya mengakomodasi desakan dari berbagai pihak yang menginginkan agar tersedia jasa transaksi keuagnan yang dilaksanakan sejalan dengan nilai moral dan prinsip-prinsip syariah Islam. Umat Islam diharapkan dapat memahami perkembangan bank syariah dan mengembangkannya apabila dalam posisi sebagai pengelola bank syariah yang perlu secara cermat mengenali dan mengidentifikasi semua mitra kerja yang sudah ada maupun yang potensial untuk pengembangan bank syariah.

\section{PEMBAHASAN}

\section{Bank Konvensional dan Bank Syariah}

Bank berasal dari kata Itali banco yang artinya bangku. Bangku inilah yang dipergunakan oleh bankir untuk melayani kegiatan operasionalnya kepada para nasabah. Istilah bangku secara resmi dan popular menjadi bank. Pada awal perkembangan perbankan di Indonesia. Perbankan diartikan sebagai badan usaha yang menghimpun dana dari masyarakat dalam bentuk simpanan dan menyalurkannya kepada masyarakt dalam rangka menignkatkan taraf hidup rakyat banyak.

Bank merupakan salah satu lembaga keuangan yang memiliki peranan penting sebagai perantara keuangan di dalam perekonomian suatu negara. Selain sebagai tempat penyimpanan deposito, tabungan, giro dan sebagai tempat meminjam dana, saat ini bank menjadi sebuah lembaga yang 
tidak dapat dipisahkan dari kehidupan masyarakat hamper diseluruh dunia. Diantara fungsi lain bank dalam dunia modern adalah sebagai penyedia layanan pembayaran belanja elektronik, tagihan telepon, tagihan listrik, dan pembayaran lainnya yang belum pernah terbayangkan sebelumnya.

Menurut UU RI no. 10 Tahun 1998 tanggal 101998 tentang perbankan, yang dimaksud dengan bank adalah "Badan usaha yang menghimpun dana dari mesarakat dalam bentuk kredit atau bentukbentuk lainnya dalam rangka meningkatkan taraf hidup rakyat banyak". Dari pengertian diatas, dapat dipahami bahwa bank merupakan perusahaan yang bergerak dibidang keuangan dan segala aktivitasnya selalu berkaitan dengan keuangan. Adapun dalam menjalankan kegiatan usahanya, bank di Indonesia dibedakan menjadi dua yaitu bank yang melaksanakan kegiatan usaha berdarkan prinsip konvensional, dan berdasarkan prinsip syariah.

Bank Konvensional merupakan bank yang telah berdiri lebih awal dibandingkan Nank Syariah di Indonesia dan memiliki fasilitas yang sudah tersebar luas di Indonesia. Dalam Kamus Besar Bahasa Indonesia, Konvensional berarti "menurut apa yang sudah menjadi kebiasaan". Dari pengertian di atas, dapat diambil kesimpulan bahwa Bank Konvensional merupakan bank yang menjalankan kegiatan usahanya dengan menerapkan metode bunga yang sudah ada terlebih dahulu dan sudah menjadi kebiasaan bankbank pada masa lalu dalam meraih keuntungan dari aktivitas bisnisnya. Dalam hal ini masayrakat di Indonesia sudah cukup terbiasa dengan pembiayaan metode bunga.

Bank merupakan salah satu lembaga keuangan yang mempunyai peranan penting di dalam perekonomian suatu negara sebagai lembaga perantara keuangan. Bank dalam Pasal 1 ayat (2) UU No. 10 Tahun 1998 tentang perubahan UU No. 7 Tahun 1992 tentang perbankan adalah badan usaha yang menghimpun dana dari masyarakat dalam bentuk simpanan dan menyalurkannya kepada masyarakat dalam bentuk kredit atau bentuk-bentuk lain dalam rangka meningkatkan taraf hidup rakyat banyak.

Sedangkan Bank Syariah merupakan bank yang mengikuti sistem ekonomi Islam. Adapun ekonomi Islam menurut Fazlurrahman dalam Farida (2011:53), "ekonomi Islam menurut para pembangun dan pendukungnya dibangun di atas atau setidaknya diwarnai oleh prinsip-prinsip religious, berorientasi dunia dan akhirat."

Pada tahun 1992 Bank Muamalat Indonesia berdiri sebagai tanda dimulainya dual Definisi bank, bank umum dan Bank Perkreditan Rakyat dalam Undang-Undang Nomor 10 Tahun 1998 Pasal 1 tentang perbankan yakni:

"Bank adalah badan usaha yang menghimpun dana masyarakat dalam bentuk simpanan dan menyalurkannya kepada masyarakat dalam bentuk kredit dan atau bentuk-bentuk lainnya dalam rangka meningkatkan taraf hidup rakyat banyak. Sedangkan pengertian bank umum adalah bank yang melaksanakan kegiatan usaha secara konvensional dan atau "berdasar prinsip syariah" yang dalam kegiatannya memberikan jasa dalam lalu lintas pembayaran. Pengertian bak perkreditan 
rakyat (BPR-Syariah) adalah bank yang melaksanakan kegiatan usaha secara konvensional atau berdasarkan prinsip syariah yang dalam kegiatannya tidak memberikan jasa dalam lalu lintas pembayaran".

Undang-Undang Nomor 10 Tahun 1998 Pasal 1 Ayat 13 tentang perbankan menyatakan apa yang dimaksud dengan prinsip syariah yakni:

"Prinsip syariah adalah aturan perjanjian berdasarkan hokum islam antara bank dan pihak lain untuk penyimpanan dana dan atau pembiayaan kegiatan usaha, atau kegiatan lainnya yang dinyatakan sesuai dengan syariah, antara lain pembiayaan berdasarkan prinsip bagi hasil (mudharabah), pembiayaan berdasarkan penyertaan modal (musyarakah), prinsip jual beli barang dengan memperoleh keuntungan (mudharabah), atau pembiayaan barang modal berdasarkan prinsip sewa murni tanpa pilihan (ijarah). Atau dengan adanya pemindahan kepemilikan atas barang yang disewa dari pihak bank oleh pihak lain (ijarah wa iqtina)".

Sedangkan dalam Undang-Undang Nomor 21 tahun 2008 pasal 1 ayat 12 tentang Perbankan Syariah menyatakan bahwa yang dimaksud dengan prinsip syariah adalah prinsip hukum Islam dalam kegiatan perbannkan berdasarkan fatwa yang dikeluarkan oleh lembaga yang memiliki kewenangan dalam penetapan fatwa di bidang syariah. Dari pengertian bank tersebut diatas, maka dapat diambil kesimpulan bahwa Bank Syariah adalah badan usaha yang menjalankan fungsi intermediasinya berdasarkan prinsip syariah atau dengan kata lain bank yang dalam aktivitasnya, baik penghimpunan dana maupun penyaluran dana memberikan imbalan atas dasar prinsip syariah.

\section{Persamaan dan Perbedaan Bank Konvensional dan Syariah}

Bank konvensional dan Bank syariah memiliki beberapa persamaan, terutama dalam sisi teknis penerimaan uang, mekanisme transfer, teknologi komputer yang digunakan, syarat-syarat umum memperoleh pembiayaan seperti KTP, NPWP, proposal, laporan keuangan, dan sebagainya. Perbedaan mendasar diantara keduanya yaitu menyangkut aspek legal, stuktur organisasi, usaha yang dibiayai dan lingkungan kerja.

Hal mendasar yang membedakan antara lembaga keuangan konvensional dengan syariah terletak pada pengembalian dan pembagian keuntungan yang diberikan oleh nasabah kepada lembaga keuangan atau yang diberikan oleh lembaga keuangan kepada nasabah. Kegiatan operasional Bank syariah menggunakan prinsip bagi hasil (Mudharabah). Bank syariah tidak menggunakan bunga sebagai alat untuk memperoleh keuntungan maupun membebankan bunga atas pinjaman karena bunga merupakan riba yang diharamkan.

Pola bagi hasil ini memungkinkan nasabah untuk mengawasi langsung kinerja Bank syariah dengan memantau jumlah bagi hasil yang diperoleh. Jika jumlah keuntungan bank semakin besar maka semakin besar pula bagi hasil yang diterima nasabah, demikian juga sebaliknya. Jumlah bagi hasil yang kecil atau mengecil dalam waktu cukup lama menjadi patokan bahwa pengelolaan bank merosot. Keadaan itu 
merupakan peringatan dini yang transparan dan mudah bagi nasabah. Berbeda dari perbankan konvensional, nasabah tidak dapat menilai kinerja hanya berpatokan pada bunga yang diperoleh.

Perbedaan tujuan dari bank konvensional dengan bank syariah; Bank konvensional didirikan untuk mendapatkan keuntungan material sebesar-besarnya, sedangkan bank syariah didirikan untuk memberikan kesejahteraan material dan spiritual. Kesejahteraan material dan spiritual tersebut didapat melalui usaha pengumpulan dan penyaluran dana yang halal. Artinya, bank syariah tidak akan menyalurkan dana untuk usaha pabrik minuman keras atau usaha lain yang tidak bisa dijamin bahwa hasilnya berasal dari kegiatan yang halal. Karena itu dapat dikatakan bahwa konsep keuntungan pada bank konvensional lebih cenderung, berfokus pada sudut keuntungan materi, sedangkan konsep keuntungan pada bank syariah harus memperhatikan keuntungan dari sudut duniawi dan ukhrawi(akhirat). Jika memang tujuan nasabah sesuai dengan tujuan bank syariah, maka secara prinsip tidak ada kekurangan dari menabung di bank syariah karena adanya keseimbangan antara duniawi dan ukhrawi. Namun apabila tujuan nasabah lebih ke aspek-aspek material, maka bisa jadi keuntungan yang diperoleh akan kurang sesuai dengan harapan.

Bank Syariah memiliki misi dan metodologi yang ekslusif, misi yang bukan sekedar ada pada jumlah nominal investasi tapi juga mencakup pada jenis, objek dan tujuannya itu sendiri. Adapun metodologinya adalah kerangka syariat dan kaidah-kaidahnya yang bersumber dari etika dan nilai-nilai syariat Islam yang universal. Berdasarkan hal tersebut, Bank syariah berfungsi sebagai sarana untuk mengumpulkan tabungan masyarakat dan mengembangkannya. Intinya bahwa Bank syariah adalah lembaga yang berfungsi untuk menginvestasikan dana masyarakat sesuai dengan anjuran Islam dengan efektif, produktif dan untuk kepentingan umat Islam. Tujuan utama dari Bank Syariah, yaitu menyatukan umat Islam, mengembalikan kekuatan, peran, dan kedudukan Islam di muka bumi ini bisa tercapai.

\section{Keunggulan dan Kelemahan Bank Syariah}

\section{1) Keunggulan dan Kelebihan Bank Syariah}

Menurut Antonio

(2008) menjelaskan tentang: 1) Kelebihan Bank Syariah terutama pada kuatnya ikatan emosional keagamaan antara pemegang saham, pengelola bank, dan nasabahnya. Dari ikatan emosional inilah dapat dikembangkan kebersamaan dalam menghadapi risiko usaha dan membagi keuntungan secara jujur dan adil. (2) Dengan adanya keterikatan secara religi, maka semua pihak yang terlibat dalam Bank Islam adalah berusaha sebaik-baiknya dengan pengalaman ajaran agamanya sehingga berapa pun hasil yang diperoleh diyakini membawa berkah. (3) Adanya Fasilitas pembiayaan (Al-Mudharabah dan Al-Musyarakah) yang tidak membebani nasabah sejak awal dengan kewajiban membayar biaya secara tetap. Hai ini adalah memberikan kelonggaran psikologis yang diperlukan nasabah 
untuk dapat berusaha secara tenang dan sungguh-sungguh. (4) Dengan adanya sistem bagi hasil untuk penyimpan dana setelah tersedia peringatan dini tentang keadaan bank yang bisa diketahui sewaktu-waktu dari naik turunnya jumlah bagi hasil yang diterima. (5) Penerapan sistem bagi hasil dan ditinggalkannya sistem bunga menjadikan Bank Islam lebih mandiri dari pengaruh gejolak moneter baik dari dalam maupun dari luar negeri.

\section{2) Kelemahan Bank Syariah}

John L. Eposito mengkritisi Ekonomi Islam dalam Farida (2011:54-55) bahwa:

Secara keseluruhan, Ekonomi Islam lebih berhasil menjelaskan apa yang bukan Ekonomi Islam, daripada menentukan apa yang membuat Ekonomi Islam juga lebih banyak mengungkap kelemahan system lain dari pada menunjukan (bahwa Ekonomi Islamsecara substansial memang lebih baik.

Menurut Adiwarman dalam Sulistiyawan (2015:1), menyatakan bahwa ada enam kelemahan Bank Syariah yang menyebabkan masih sedikitnya masyarakat menjadi nasabah Bank Syariah. Adapun kelemahan itu meliputi (1) Promosi bank syariah kurang menyeluruh ke berbagai msyarakat, (2) Kantor yang dimiliki sedikit, (3) Ketidaktahuan masyarakat, (4) Fasilitas anjungan tunai mandiri (ATM) jumlahnya sedikit, (5) Produkproduknya tidak diketahui masyarakat tidak diketahui masyarakat,
Kurangnya fasilitas. Selain itu, kelemahan bank syariah adalah sebagai berikut:

a. Jaringan kantor Bank Syariah belum luas.

b. SDM Bank Syariah masih sedikit.

c. Pemahaman masyarakat tentang Bank Syariah masih kurang.

d. Kekeliruan penilaian proyek berakibat lebih besar daripada Bank Konvesional

\section{Pencapaian Bank Syariah}

Perbankan di Indonesia kini semakin diramaikan adanya Bank Syariah yang menawarkan produk keuangan dan investasi dengan cara yang berbeda dibanding Bank Konvensioal yang sudah lama ada. Meskipun masih dianggap pendatang baru, Perbankan Syariah berkembang cukup pesat. Hal itu dapat dimaklumi dengan status Indonesi sebagai negara muslim terbesar di dunia sehingga perbankan yang menggunakan hukum dan asas Islam akan lebih diminati. Seolah tidak mau kehilangan momentum, saat ini bank-bank konvensional di Indonesia ikut mendirikan institusi syariah ataau unit usaha syariah sendiri. Hal ini dilakukan untuk menggaet lebih banyak nasabah yang tertarik dengan keunggulan Bank Syariah.

Mayoritas masyarakat Indonesia adalah muslim, maka hadirnya bank syariah telah menjadi kebutuhan masyarakat bahkan sebelum Indonesia merdeka. Sejarah mencatat K.H Mas mansyur, ketua pengurus besar Muhammadiyah periode 1937-1944 pernah menyatakan bahwa umat islam di Indonesia terpaksa menggunakan jasa bank konvensional karena belum memiliki lembaga yang bebas riba saat itu. 
Tahun 1983 pemerintah Indonesia pernah berencana menerapkan "sistem bagi hasil" dalam perkreditan yang merupakan konsep dari perbankan syariah. Kondisi perbankan Indonesia saat itu sedang tidak stabil karena Bank Indonesia tidak bisa mengendalikan tingkat suku bunga di bankbank yang membungbung tinggi. Sehingga pemerintah mengeluarkan deregulasi tanggal 1 juni 1993 yang menimbulkan kemungkinan bank mengambil untuk dari bagi hasil sistem kredit. Lima tahun kemudian, pemerintah menganggap bisnis perbankan harus dibuka seluas-luasnya untuk menunjang pembangunan. Akhirnya pada tanggal 27 oktober 1988, pemerintah pun mengeluarkan paket Kebijaksanaan Pemerintah Bukan Oktober (PAKTO) untuk meliberalisasi perbankan. Meskipun lebih banyak bank konvensional yang berdiri, beberapa bank daerah yang berasaskan syariah juga mulai bermunculan.

Tahun 1990, MUI membentuk kelompok kerja untuk mendirikan Bank Islam di Indonesia. Ini meruakam cikal bakal lahirnya perbankan syariah di Indonesia. Pada tahun 1992, bank syariah pertama di Indonesia yaitu Bank Muamalat pun lahir.

Berdasarkan data statistika perbankan syariah yang dipublikasikan oleh bank Indonesia, pada tahun 1998 terdapat satu bank umum syariah dan 76 bank perkreditan rakyat syariah. Menurut Hadad Dalam Yanita (2015:1).

"Per maret 2015, industri perbankan syariah terdiri dari 12 Bank Umum Syariah, 22 unit usaha syariah yang dimiliki bank umum konvensional, dan 163 Bank Perkreditan Rakyat Syariah(BPRS) dengan total aset sebesar Rp 264,81 trilius dengan pangsa pasar (market share) 4,88\%. Sementara itu, jumlah pelaku industry keuangan non-bank (IKNB) syariah 98 lembaga di luar LKM, yang terdiri atas usaha jasa takaful atau asuransi syariah yang mengelola aset senilai Rp 23,80 trilliun, usaha pembiayaan syariah yang mengelola aset senilai Rp 19, 63 trilliun, dan lembaga keuangan syariah lainnya dengan aset senilai Rp 12,86 triliun". Namun, terlepas dari pencapaian tersebut, Bank Syariah masih belim mampu mencapai target market share yang pernah ditargetkan mampu dicapai pada tahun 2008 yaitu sebebar $5 \%$.

\section{Sejarah Bank Syariah}

Perkembangan institusi keuangan syariah secara informal telah dimulai sebelum dikeluarkannya kerangka hukum formal sebagai landasan operasional perbankan di Indonesia. Beberapa badan usaha pembiayaan non- Bank telah didirikan sebelum tahun 1992 yang telah menerapkan konsep bagi hasil dalam kegiatan operasionalnya. Hal tersebut menunjukkan kebutuhan masyarakat akan hadirnya institusi-institusi keuangan yang dapat memberikan jasa keuangan yang sesuai dengan syariah.

Kebutuhan masyarakat tersebut telah terjawab dengan terwujudnya sistem perbankan yang sesuai syariah. Pemerintah telah memasukkan kemungkinan tersebut dalam undang-undang yang baru. UndangUndang No.7 Tahun 1992 tentang Perbankan secara implisit telah membuka peluang kegiatan usaha perbankan yang memiliki dasar operasional bagi hasil yang secara rinci dijabarkan dalam Peraturan Pemerintah No. 72 Tahun 1992 tentang 
Bank Berdasarkan Prinsip Bagi Hasil. Ketentuan tersebut telah dijadikan sebagai dasar hukum beroperasinya Bank syariah di Indonesia. Periode 1992 sampai 1998, hanya terdapat satu Bank Umum Syariah dan 78 Bank Perkreditan Rakyat Syariah (BPRS) yang telah beroperasi.

Tahun 1998 muncul UU No. 10 tahun 1998 tentang perubahan UU No 7 Tahun 1992 tentang perbankan. Perubahan UU tersebut menimbulkan beberapa perubahan yang memberikan peluang yang lebih besar bagi pengembangan Bank syariah. Undangundang tesebut telah mengatur secara rinci landasan hukum serta jenis-jenis usaha yang dapat dioperasikan dan diimplementasikan oleh Bank syariah. Undang-undang tersebut juga memberikan arahan bagi Bank konvensional untuk membuka cabang syariah atau bahkan mengkonversi diri secara total menjadi Bank syariah.

Akhir tahun 1999, bersamaan dengan dikeluarkannya UU perbankan maka munculah bank-bank syariah umum dan Bank umum yang membuka unit usaha syariah. Sejak beroperasinya Bank Muamalat Indonesia (BMI), sebagai Bank syariah yang pertama pada tahun 1992, data Bank Indonesia per 30 Mei 2007 menunjukkan bahwa saat ini perbankan syariah nasional telah tumbuh cepat, ketika pelakunya terdiri atas 3 Bank Umum Syariah (BUS) antara lain: Bank Muamalat, Bank syariah Mandiri, 23 Unit Usaha Syariah (UUS), dan 106 Bank Perkreditan Rakyat Syariah (BPRS), sedangkan asset kelolaan perbankan syariah nasional per Mei 2007 telah berjumlah Rp. 29 triliyun. Perkembangan Bank umum syariah dan Bank konvensional yang membuka cabang syariah juga didukung dengan tetap bertahannya Bank syariah pada saat perbankan nasional mengalami krisis cukup parah pada tahun 1998.

Sistem bagi hasil perbankan syariah yang diterapkan dalam produk-produk Bank Muamalat menjadikan bank tersebut relatif lebih mampu mempertahankan kinerjanya dan tidak bergantung pada tingkat suku bunga simpanan yang melonjak sehingga, beban operasionalnya lebih rendah dari bank konvensional.

Sebagai salah satu lembaga keuangan, bank perlu menjaga kinerjanya agar dapat beroperasi secara baik. Terlebih lagi Bank syariah harus bersaing dengan Bank konvensional yang dominan dan telah berkembang pesat di Indonesia. Persaingan yang semakin tajam ini harus di ikuti dengan manajemen yang baik untuk bisa bertahan di industri perbankan. Salah satu hal yang harus diperhatikan oleh bank untuk bisa terus bartahan hidup adalah kinerja (kondisi keuangan) bank. market share dalam bersaing dengan Bank Konvensional yang telah berdiri lebih awal.

\section{METODE PENELITIAN}

Penelitian ini merupakan penelitian deskriftif kualitatif. Tujuan penelitian ini dalah menafsirkan dan menuturkan data yang bersangkutan dengan situasi yang sedang terjadi, sikap/pandangan yang terjadi didalam masyarakat, pertentangan 2 keadaaan atau lebih, pengaruh terhadap suatu kondisi dll. Didalam penelitian deskriptif kualitatif ini, peneliti disini menggunakan kajian studi pustaka mencari informasi lewat buku, majalah, koran, dan literature lainnya untuk membentu sebuah landasan teori (Arikunto, 2006). Penelitian ini juga untuk menelaah sumber-sumber 
tertulis seperti jurnal ilmiah, buku referesni, literature, ensiklopedia, karangan ilmiah, karya ilmiah serta sumber-sumber lain baik dalam bentuk tulisanatau dalam format digital yang relevan dan berhubungan dengan objek yang sedang diteliti. Adapun yang menjadi objek kajian penelitian ini adalah berupa teks-teks atau tulisan-tulisan yang menggambarkan dan memaparkan tentang sejarah dan perkembangan Bank Syariah di Indonesia.

\section{Perkembangan Bank Syariah di Indonesia}

Pelopor berdirinya perbankan syariah di Indonesia adalah Bank Muamalat pada tahun 1991. Bank ini dilahirkan oleh Majelis Ulama Indonesia, Ikatan Cendikiawan Muslim Indonesia (ICMI), pengusaha Muslim dan juga pemerintah. Sayangnya bank tersebut kurang popular dan kinerjanya stagnan, baru setelah krisis ekonomi dan reformasi, Bank Muamalat mulai dilirik nasabah.

Perkembangan perbankan syariah di Indonesia telah menjadi tolak ukur keberhasilan eksistensi ekonomi syariah. Bank muamalat sebagai bank syariah pertama dan menjadi pioneer bagi bank syariah lainnya telah lebih dahulu menerapkan system ini ditengah menjamurnya bank-bank konvensional. Krisis moneter yang terjadi pada tahun 1998 telah menenggelamkan bank-bank konvensional dan banyak yang dilikuidasi karena kegagalan system bunganya. Sementara perbankan yang menerapkan system syariah dapat tetap eksis dan mampu bertahan.

Tidak hanya itu, di tengah-tengah krisis keuangan global yang melanda dunia pada penghujung akhir tahun 2008, lembaga keuangan syariah kembali membuktikan daya tahannya dari terpaan krisis. Lembagalembaga keuangan syariah tetap stabil dan memberikan keuntungan, kenyamanan serta keamanan bagi para pemegang sahamnya, pemegang surat berharga, peminjam dan para penyimpan dana di bank-bank syariah.

Hal ini dapat dibuktikan dari keberhasilan bank Muamalat melewati krisis yang terjadi pada tahun 1998 dengan menunjukkan kinerja yang semakin meningkat dan tidak menerima sepeser pun bantuan dari pemerintah dan pada krisis keuangan tahun 2008, bank Muamalat bahkan mampu memperoleh laba Rp. 300 miliar lebih.

Perbankan syariah sebenarnya dapat menggunakan momentum ini untuk menunjukkan bahwa perbankan syariah benar-benar tahan dan kebal krisis dan mampu tumbuh dengan signifikan. Oleh karena itu perlu langkah-langkah strategis untuk merealisasikannya.

Langkah strategis pengembangan perbankan syariah yang telah di upayakan adalah pemberian izin kepada bank umum konvensional untuk membuka kantor cabang Unit Usaha Syariah (UUS) atau konversi sebuah bank konvensional menjadi bank syariah. Langkah strategis ini merupakan respon dan inisiatif dari perubahan Undang - Undang perbankan no. 10 tahun 1998. Undang-undang pengganti UU no.7 tahun 1992 tersebut mengatur dengan jelas landasan hukum dan jenisjenis usaha yang dapat dioperasikan dan diimplementasikan oleh bank syariah.

Tabel 1.1 Perkembangan Bank Syariah 


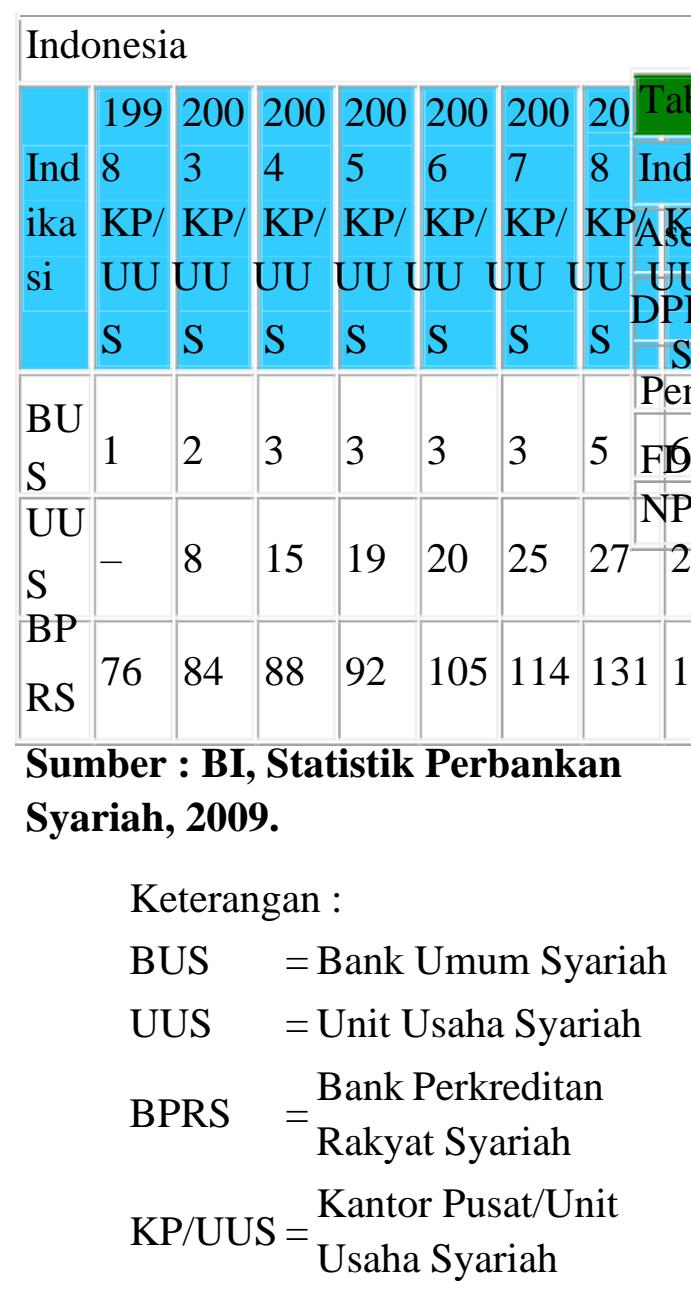

Tabel 1.1 menunjukkan perkembangan perbankan syariah berdasarkan laporan tahunan BI 2009 (Desember 2009). secara kuantitas, pencapaian perbankan syariah sungguh membanggakan dan terus mengalami peningkatan dalam jumlah bank. Jika pada tahun 1998 hanya ada satu Bank Umum Syariah dan 76 Bank Perkreditan Rakyat Syariah, maka pada Desember 2009 (berdasarkan data Statistik Perbankan Syariah yang dipublikasikan oleh Bank Indonesia) jumlah bank syariah telah mencapai 31 unit yang terdiri atas 6 Bank Umum Syariah dan 25 Unit Usaha Syariah. Selain itu, jumlah Bank Perkreditan Rakyat Syariah (BPRS) telah mencapai 139 unit pada periode yang sama.
Tabel $\quad 1.2$ menunjukkan perkembangan terakhir indikasi-indikasi perbankan syariah. Perkembangan asset perbankan syariah meningkat sangat signifikan dari akhir tahun 2008 sampai dengan akhir tahun 2009 sebesar lebih dari 33.37 persen. Penghimpunan dana dan pembiayaan mencapai peningkatan sebesar 41.84 dan 22.74 persen.

Jika dilihat dari rasio pembiayaan yang disalurkan dengan besarnya dana pihak ketiga (DPK) yang dinyatakan dengan nilai Financing to Deposit Ratio (FDR), maka bank syariah memiliki ratarata FDR sebesar 97.65 persen. Berbeda dengan tahun-tahun sebelumnya dan tahun sesudahnya, pada tahun 2008 Financing to Defosit Ratio perbankan syariah lebih dari $100 \%$. Tingginya tingkat FDR tersebut karena pembiayaan yang disalurkan selama bulan maret - November 2008 lebih besar dari Dana Pihak ketiga.

Yang perlu di catat disini adalah, meskipun pembiayaan yang disalurkan lebih besar dari DPK, tetapi tingkat kegalalan bayar atau yang dinyatakan dalam Non Performing Financing (NPF) ternyata lebih sedikit dari periode tahun 2006-2007, yakni hanya sebesar $3.95 \%$, masih dibawah 
batas ketentuan minimal sebesar 5 persen. Artinya bank syariah betul betul menjalankan fungsinya sebagai lembaga intermediasi keuangan dengan tidak mengabaikan prinsip kehati-hatian. Selain itu juga, secara keseluruhan perbankan syariah relatif lebih sehat.

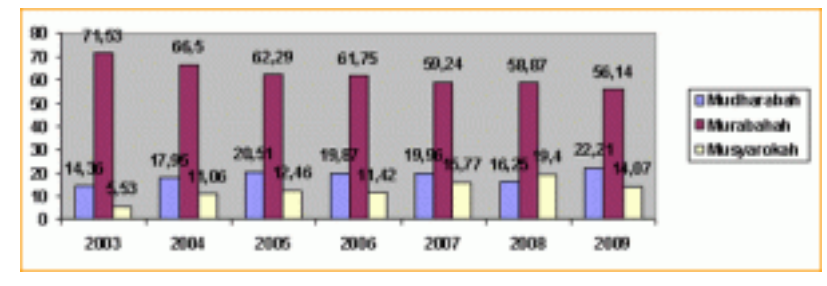

Pada grafik 1.4 terlihat bahwa persentase pembiayaan murabahah dengan Perbandingan Pangsa Perbankan Syariah Terhadap Total Bank

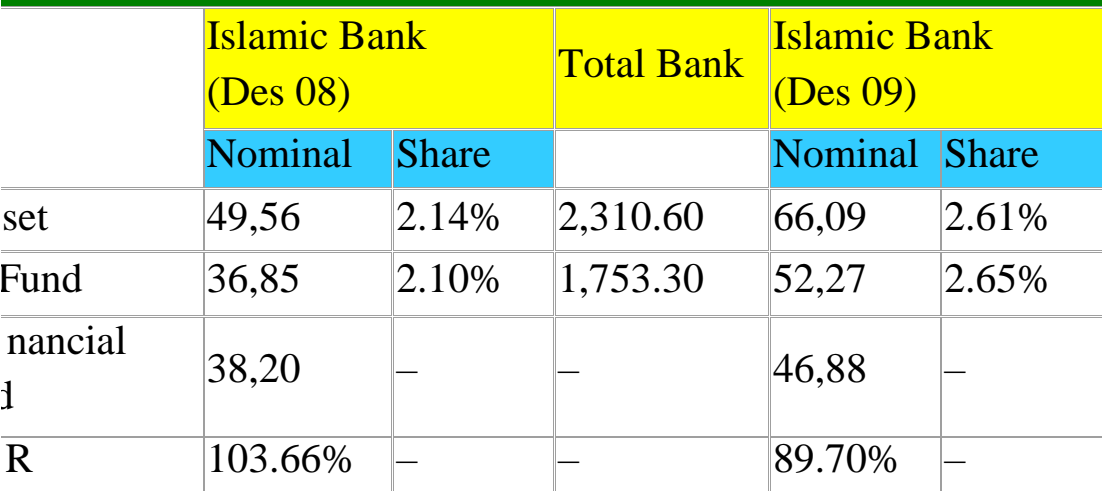

Sumber: BI, Statistik Perbankan Syariah, 2009

Pada tabel 1.3 terlihat bahwa pangsa perbankan syariah meningkat jika dibandingkan dengan tahun 2008 pada bulan yang sama, yaitu asset menjadi $2.61 \%$ meningkat sebesar $0.47 \%$, Deposit Fund atau DPK juga mengalami pertumbuhan menjadi $2,02 \%$, meningkat $0,24 \%$. hal ini menunjukkan kinerja dan potensi perbankan syariah mengalami perkembangan yang baik.

\section{Grafik 1.4. Komposisi Pembiayaan Bank Syariah} mendominasi jauh di atas tprital Barmbiay ian mudharabah dan nusyarokah. P Ida tahun 2003 terjadi perberdaan terlesar dimana persentase peroblaydan myarabah dan musyarokah

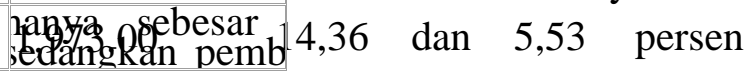
7-0,81 persen. Nayaan murabahah sebesar sembiayaan de mun sayangnya, meskipun $\mathrm{s}^{-}$elalu mengalarngan prinsip jual - beli i penurun setiap tahunnya namun jumlah persentasenya tidak pernah kurang dari lima-puluh persen. Semestinya, pembiayaan dengan akad mudharabah dan akad musyarakah harus lebih banyak. Karena pada akad inilah karakteristik dasar perbankan syariah terbentuk. Kedua akad tersebut merupakan akad dengan sistem bagi hasil. Perbankan syariah dengan sistem bagi hasil inilah yang menjadi pembeda dengan bank konvensional.

\section{KESIMPULAN}

Perbankan Syariah sering disebut juga Perbankan Islam, yaitu perbankan yang pelaksanaannya berdasarkan hukum Islam atau syariat. Karena berdasarkan hukum Islam, maka perbankan syariah tidak mengenal adanya "bunga pinjaman" alias interest rate. Bunga pinjaman dianggap riba dan berdosa. Yang dikenal di perbankan syariah adalah "sistem bagi hasil" atau Nisbah yang prosesnya sama-sama 
diketahui dan disetujui oleh bank dan pihak nasabah. Kegiatan operasional Bank syariah menggunakan prinsip bagi hasil (Mudharabah).

Bank Syariah pada dasarnya memiliki potensi dan peluang yang luar biasa besar. Pertumbuhan dari segi aset pun sudah membuktikan bahwa Bank Syariah merupakan model bank yang sangat ideal untuk mendorong kemajuan perekonomian Negara. Namun dari segi kualitas pelayanan Bank Syariah harus mengejar ketinggalannya dari Bank Konvensional yang telah lebih awal berdiri. Selain itu, untuk menghasilkan persaingan yang produktif antara Bank Syariah dan Bank Konvensional diperlukan peraturan perbankan khusus untuk Perbankan Syariah sehingga mampu menjalankan tugasnya tanpa harus mengekor kepada sistem konvensional.

\section{DAFTAR PUSTAKA}

Abadi, R. (2015, 06 09). Sejarah dan

Perkembangan Bank Syariah Di Indonesia. Dipetik 10 03, 2015, dari Cermati:

http://www.cermati.com/artikel/sejar ah-dan-perkembangan-bank-syariahdi-indonesia

Choir. (2010, 03 31). Kelebihan dan Kendala Bank Syariah. Dipetik 10 03, 2015, Dari Zona Ekonomi islam: http://zonaekis.com/kelebihan-dankendala-bank-syariah/

Analisis Perbandingan Kinerja Keuangan Bank Konvensional dan Bank Syariah. (2010). 1-3.

Antonio, M. S., \& Muhammad. (2008). Bank Syariah: Analisis Kesehatan, Peluang, Kelemahan dan Ancaman. Yogyakarta: Ekonisia.
Arikunto, Suharsimi. 2006. Prosedur

Penelitian: Suatu Pendekatan

Praktik. Jakarta: Rineka Cipta

Fahmi, I. (2012). Percepatan Pertumbuhan

Perbankan Syariah. Program

Pascasarjana Manajemen dan Bisnis IPB. 1-2

Farida, A. (2011). Sistem Ekonomi Indonesia. Bandung: Pustaka Setia.

Hirsanuddin. (2008). Hukum Perbankan Syariah di Indonesia, Pembiayaan Bisnis dengan Konsep Kemitraan. Yoyakarta: Genta Press.

Mursito, I. (2014, 11 10). Keunggulan Sistem Perbankan Syariah (Perbandingan dengan Sistem Konvensional). Dipetik 10 03, 2015, dari Kompasia: http://www.kompasiana.com/ianmurs ito/keunggulan-sistem-perbankansyariah-perbandingan-dengan-sistemkonvensional_54f3cdd4745513902b6 c7f39

Saksono. (2013, 12 21). Kelebihan Dan Kekurangan Bank Syariah. Dipetik 10 03, 2015, dari Harian Ekonomi Neraca:

http://www.neraca.co.id/article/3640

5/kelebihan-dan-kekurangan-banksyariah

Suprayogi, N. (2013, 30 01). Kenapa Bank Syariah Kalah Bersaing. Dipetik $10 \quad 03, \quad 2015$, dari Universitas Airlangga:

Sparta. (2008). Mengenal Keunggulan Praktek Perbankan Syariah di Indonesia. Jurnal Ekonomi, 347-357.

Ridwan, A. H. (2013). Manajemen Baitul Mal wa Tamwil. Bandung: Pustaka Setia. 
Strategi Persaingan Bank Syariah Terhadap

Bank Konvensional (2010). 1-3

http://www.bi.go.id

https://www.cermati.com/artikel/sejarah-

dan-perkembangan-bank-syariah-di-

indonesia

http://portalhiuinjakarta.blogspot.co.id/2009

/03/bank-konvensional-vs-bank-

syariah.html

http://dhayattoni80.blogspot.co.id/2013/05/

perkembangan-bank-syariah-di-

indonesia.html

https://eriellg.wordpress.com/2016/05/22/pe

rsaingan-bank-syariah-dan-bank-

konvensional/ 